\title{
Location Efficiency of Healthcare Facilities in Ikot Ekpene Local Government of Akwa-lbom State: the Role of Geographical Information System (GIS)
}

\author{
Elijah Akwarandu Njoku ${ }^{1, *}$, Patrick Etim Akpan ${ }^{2}$ \\ ${ }^{1}$ Department of Geography and Regional Planning, University of Benin, Benin City, Nigeria \\ ${ }^{2}$ Department of Urban and Regional Planning, Akwa Ibom Sate Polytechnic, Ikot Osurua, Nigeria \\ *E-mail address: voices4andy@yahoo.com
}

\begin{abstract}
Given the effect of locational decisions on access and utilization of healthcare facilities in any society, the current study attempted an evaluation of the locational efficiency of available health facilities in Ikot Ekpene LGA with a view to ascertain the distributional pattern of the health care centers in the study area. It was discovered that health care centers in the area are randomly distributed but moderately concentrated in a few wards leaving more than half the area under-served. Using a WHO population/distance criterion of $1 / 4 \mathrm{~km}$, it is shown that only a small portion of the study area has effective access to healthcare facilities. Potential sites for location of additional health centers were suggested and the capability of Geographical Information System (GIS) in spatial planning and healthcare facility management is demonstrated.
\end{abstract}

Keywords: GIS; Utilization; Healthcare; Locational; Database

\section{INTRODUCTION}

The importance of effective and accessible health care system in any country cannot be over-emphasized. In Nigeria, the provision of health care facilities is the responsibility of all the three tiers of government (Abbas et al, 2012). However, due to high demand on and perhaps poor quality service delivery by the public health facilities, the private sector is playing a visible complimentary role in the provision of healthcare facilities in Nigeria.

While the private sector is driven primarily by economic considerations in their location decisions, the public sector is apparently concerned with maximizing access of the target population to the facilities. Recent studies have established a correlation between different types of access (geographical, temporal and financial) and effective utilization of healthcare facilities and services (see Schoeps et al, 2011, Moisi et al, 2010 and Malqvist et al, 2010). Although a lot of money is budgeted for healthcare delivery each year in Nigeria (more than $4.6 \%$ of annual budget), inadequacy of fund and excessive administrative and bureaucratic bottleneck have meant that aggregate demand for health care services has always outstripped the supply. 
But apart from quantitative and qualitative shortage in the provision of health care services in Nigeria, the few available facilities are not efficiently distributed within the population it is meant to serve with the effect that some segments of the population are deprived of access to this important public service (Onokerhoraye, 1976).

Given the importance of healthcare services to any society, the enormous amount of money expended on its provision yearly and the impact of accessibility on the its utilization, it is imperative to ask therefore: how do public decision makers determine the efficient location points for health facilities to maximize accessibility as well as utilization? Suggesting a solution to the above question is the crux of this paper.

Among the many tools for solving spatial locational problems, the capability of Geographical Information System (GIS) in spatial planning and management has been acknowledged. GIS is a robust suite of technical software designed to accept, analyze, store and output geo-based data.

GIS has been applied in different geo-location, visualization and numerous decision support contexts. In the last few decades however, GIS application in health care facility and services management has become widespread and indispensible. As far back as 1854, John Snow made one of the foremost applications of GIS to health mapping. He used GIS to map disease outbreak in Broad Street, USA and was able to trace their cause and source (Law et al, 1998). Since then, GIS has seen notable patronage in health facility location, mapping, analyses and services demand forecasts.

In Nigeria, Abbas et al (2012) created a GIS database of health facilities in Chikun local government and analyzed their spatial distribution based on given accessibility and locational efficiency criteria. Based on his analysis, new points of potential locations were suggested. Also, Njoku (2001) attempted an assessment of the locational distribution of maternity centers in Ibadan North Local Government. Using 'proximity to road' and 'areal size' as criteria, he analyzed the observed pattern of health centers in the study area.

Apart from analyzing spatial location of health care facilities, GIS has also been deployed in mapping, visualizing and monitoring disease diffusion. For instance, Dzikwi and Abbas (2012) mapped diffusion of rabbies in Kaduna state using data collected from ministry of Agriculture. GIS and epidemiology literature is replete with similar efforts to understand the geography of disease (see Rytkonen and Mika, 2004, Pyle, 1979).

Given the importance of healthcare delivery in any society and the government effort to raise the quality of life of its citizenry through healthcare provision in Ikot Ekpene LGA, it becomes imperative to evaluate the efficiency of current locational pattern of available healthcare facilities in the study area with a view to ensuring efficiency and maximum possible utilization.

Consequently, Following WHO (1997) recommendation for health facility planning in developing economies, the current study aimed at evaluating the locational efficiency of health care facilities in Ikot-Ekpene LGA using a maximum $1 / 4 \mathrm{~km}$ distance/settlement threshold. To achieve the above aim, the following objectives were set:

- To create a GIS-readable database of healthcare facilities in Ikot-Ekpene LGA

- Analyze the locational and distributional pattern of the healthcare facilities in the study area.

- Suggest efficient and equitable location of healthcare facilities in the study area using WHO distance criteria. 


\section{GEO-HISTORICAL SETTING OF THE STUDY AREA}

Ikot Ekpene LGA lies between latitudes $5^{\circ} 10^{\prime}$ and $5^{\circ} 30^{\prime}$ North and longitudes $7^{\circ} 30^{\prime}$ and $7^{\circ} 45^{\prime}$ East. The LGA is known as a regional centre of commerce, with notable exports of palm products, especially palm oil, kernels, raffia products including raffia fibers and its sweet wine, as well as ground crops like yams, cassava, taro, and corn which attract large population from the neighboring towns. Ikot Ekpene lies on the North-Western flank of Akwa Ibom State. Its position makes it one of the economic gateways to Akwa Ibom State. Ikot Ekpene is a historical local government administration in Nigeria, as it became a premier model local government administration in 1951.

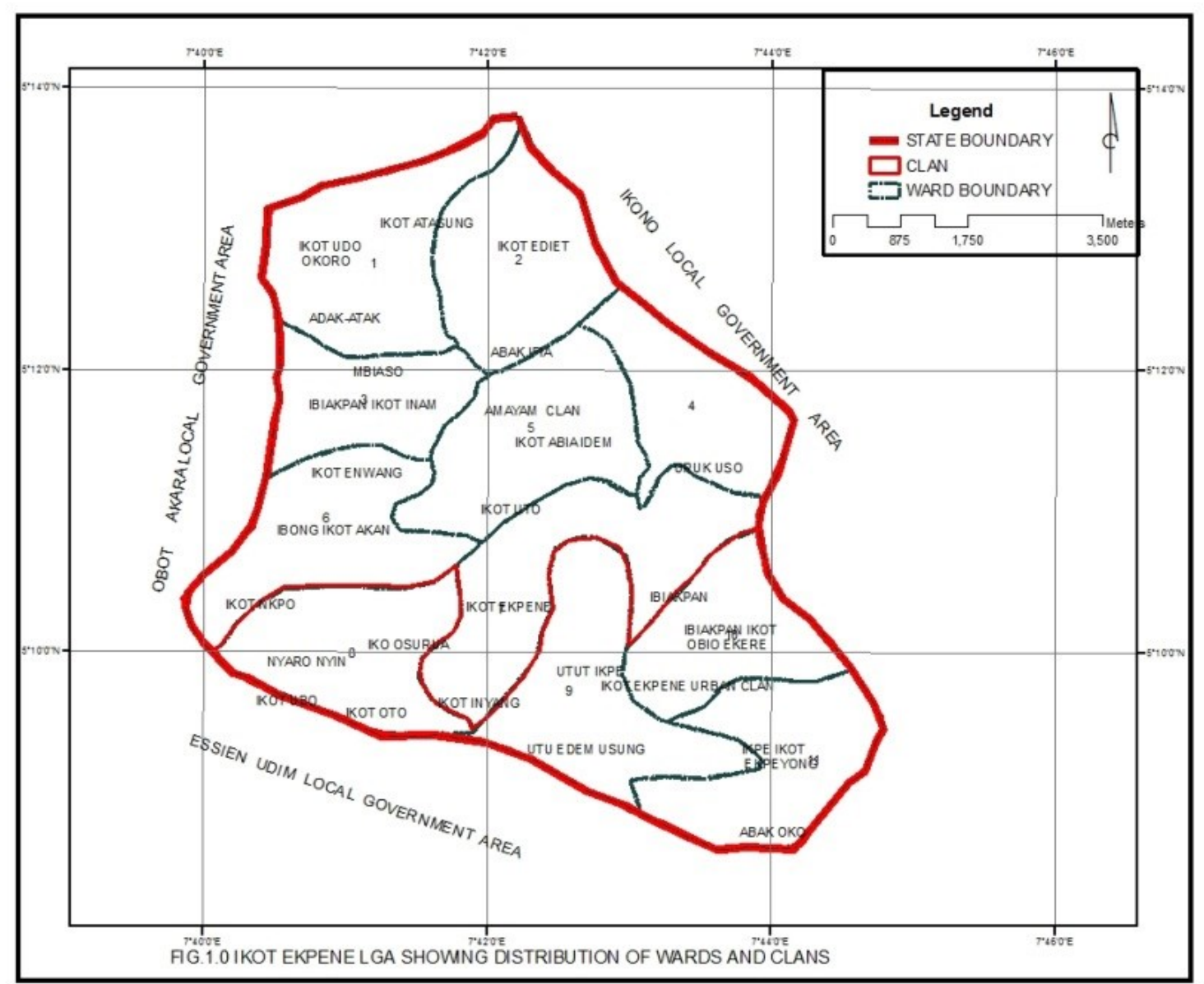

Fig. 1. Map of Ikot Ekpene Local Government Area.

The town is located on the highway that parallels the coast, between Calabar to the south east and Aba to the west, with the state capital, Uyo. Umuahia is the next major town to the north. 
Fig. 2. Table of Healthcare facilities in Ikot-Ekpene.

\begin{tabular}{|c|c|c|c|c|}
\hline $\mathbf{S} / \mathbf{N}$ & LAT & LONG & NAME/ADDRESS & OWNERSHIP \\
\hline 01 & 0357445 & 0572140 & $\begin{array}{c}\text { General Hopital, Ikot Ekpene ABAK } \\
\text { ROAD }\end{array}$ & PUBLIC \\
\hline 02 & 0358793 & 0571635 & $\begin{array}{l}\text { INFECTIOUS DISEASE HOSPITAL } \\
\text { (IDH), UYO ROAD }\end{array}$ & PUBLIC \\
\hline 03 & 0355959 & 0572678 & $\begin{array}{c}\text { Demark Clinic and Maternity, } 9 \\
\text { Library Avenue Ikot Ekpene }\end{array}$ & PRIVATE \\
\hline 04 & 0356405 & 0572927 & $\begin{array}{l}\text { Nse-Abasi maternity Home. NO.2 } \\
\text { Queen Street Clinic }\end{array}$ & PRIVATE \\
\hline 05 & 0356837 & 0572883 & Boron Clinic, NO.14 progress road & PRIVATE \\
\hline 06 & 0358317 & 0571836 & $\begin{array}{c}\text { Alpha Clinic and maternity, } 24 \text { old Itu } \\
\text { Road }\end{array}$ & PRIVATE \\
\hline 07 & 0358643 & 0358643 & Carudo Clinic, Ekoiso Road & PRIVATE \\
\hline 08 & 0358720 & 0572233 & Divine Clinic, Church Road & PRIVATE \\
\hline 09 & 0358497 & 0572434 & $\begin{array}{l}\text { Ndiana-Abasi Medical center NO.56 } \\
\text { Essien Road, }\end{array}$ & PRIVATE \\
\hline 10 & 0358300 & 0572952 & 50 legg clinic, Ikot Ebie yem Road & PRIVATE \\
\hline 11 & 0357559 & 0570995 & $\begin{array}{l}\text { Ufan-Abasi Clinic and maternity, No. } \\
12 \text { new stadium Road }\end{array}$ & PRIVATE \\
\hline 12 & 0357989 & 0571496 & $\begin{array}{c}\text { Angel Diagnostic center Nto Efa close } \\
\text { off Anwa Udo Akai }\end{array}$ & PRIVATE \\
\hline 13 & 0357887 & 0572106 & $\begin{array}{l}\text { His Word Medical Centre, } 45 \text { Atan } \\
\text { Road }\end{array}$ & PRIVATE \\
\hline 14 & 0367658 & 053266 & $\begin{array}{l}\text { Evergreen medical center4 Otong } \\
\text { Road Ikot Ekpene, }\end{array}$ & PRIVATE \\
\hline 15 & $\begin{array}{c}0035747 \\
5\end{array}$ & 0573306 & $\begin{array}{l}\text { Bridge medical center and maternity, } \\
\text { No. } 6 \text { Ukam Road }\end{array}$ & PRIVATE \\
\hline 16 & 0356964 & 0573808 & $\begin{array}{l}\text { Salthon medical center and maternity, } \\
\text { No. } 9 \text { Kono Road Ikot Ekpene }\end{array}$ & PRIVATE \\
\hline 17 & 0356230 & 0573547 & $\begin{array}{l}\text { Sunshine Clinic in front of the Clinic, } \\
\text { No. } 29 \text { Ekong Road }\end{array}$ & PRIVATE \\
\hline 18 & 0356050 & 0573761 & $\begin{array}{c}\text { Victory clinic, No. } 53 \text { Ibong Road, Ikot } \\
\text { Ekpene }\end{array}$ & PRIVATE \\
\hline 19 & 0357031 & 0573349 & $\begin{array}{l}\text { Tominon specialist clinic, No. } 4 \text { Ibong } \\
\text { Road, Ikot Ekpene }\end{array}$ & PRIVATE \\
\hline 20 & 0357203 & 0573534 & $\begin{array}{c}\text { Emem-Obong maternity home and } \\
\text { clinic, No. } 6 \text { Akpan Umoh lane off } \\
\text { Umo-obot }\end{array}$ & PRIVATE \\
\hline
\end{tabular}




\section{MATERIALS AND METHODS}

\section{Data acquisition and Mapping}

Using analogue data sourced from ministry of health, Uyo, a digital GIS-readable database was constructed on the available healthcare facilities in the LGA.

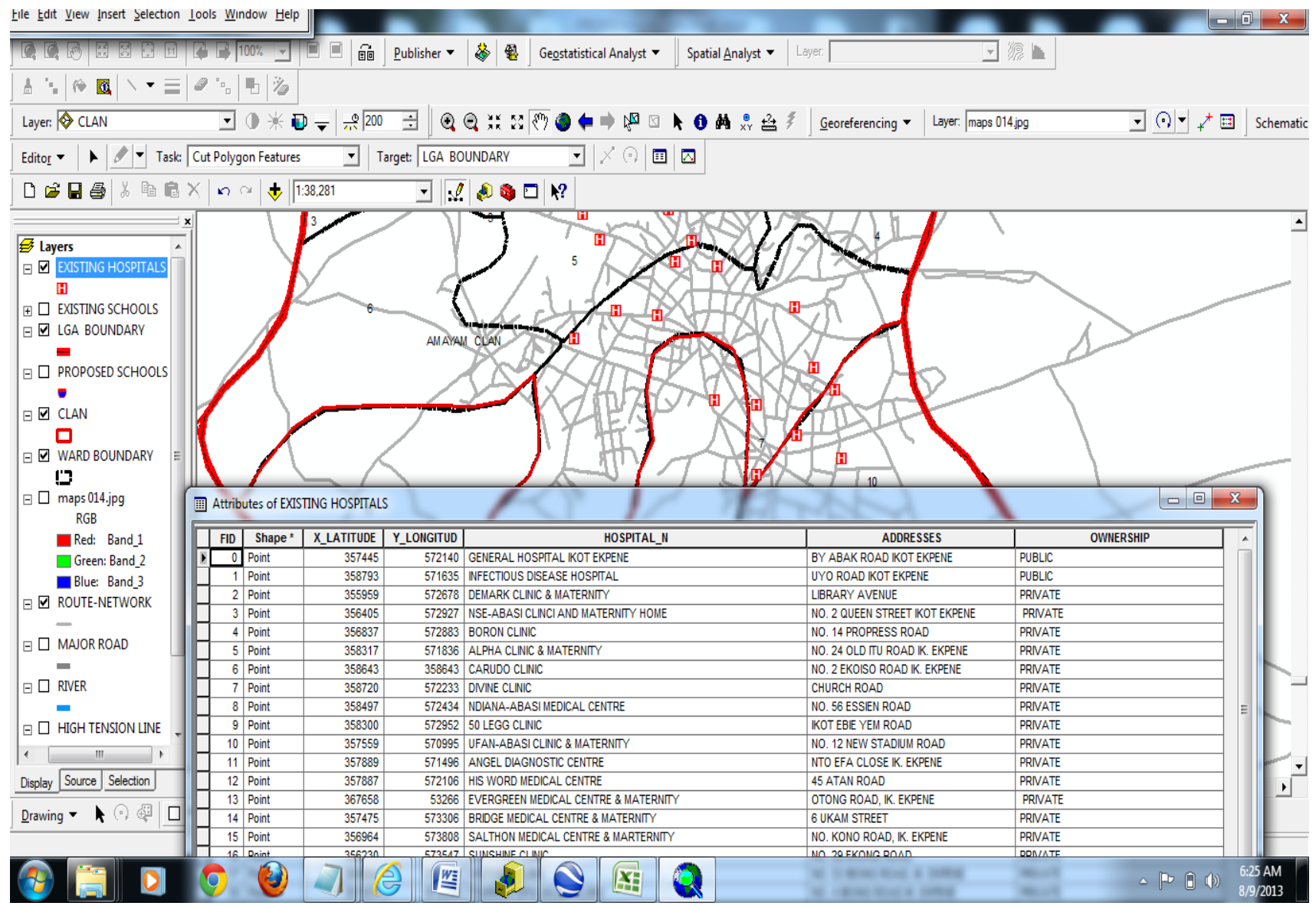

Fig. 3. GIS database of Healthcare facilities in the study area.

The study utilized data containing the comprehensive list of healthcare facilities (public and private) and their coordinates in Ikot Ekpene LGA. The Political map of Ikot Ekpene LGA was sourced from the local government to serve as the base map. Global Positioning System (GPS) was used to collect coordinate points of the health care centers in the local government as in Table 1 below.

The data was disaggregated according to location of health care facilities. A GIS database was created using Microsoft excell 2007 and ArcGIS 9.2 software. The location of each health care facilities was used to analyze general spatial distribution within the study area. To create the $1 / 4$ distance buffer map, the data was exported into Arcmap GIS software with Spatial Analyst extension.

Data containing the list of health care centers and their addresses in Ikot Ekpene LGA was also subjected to GIS analyses. 


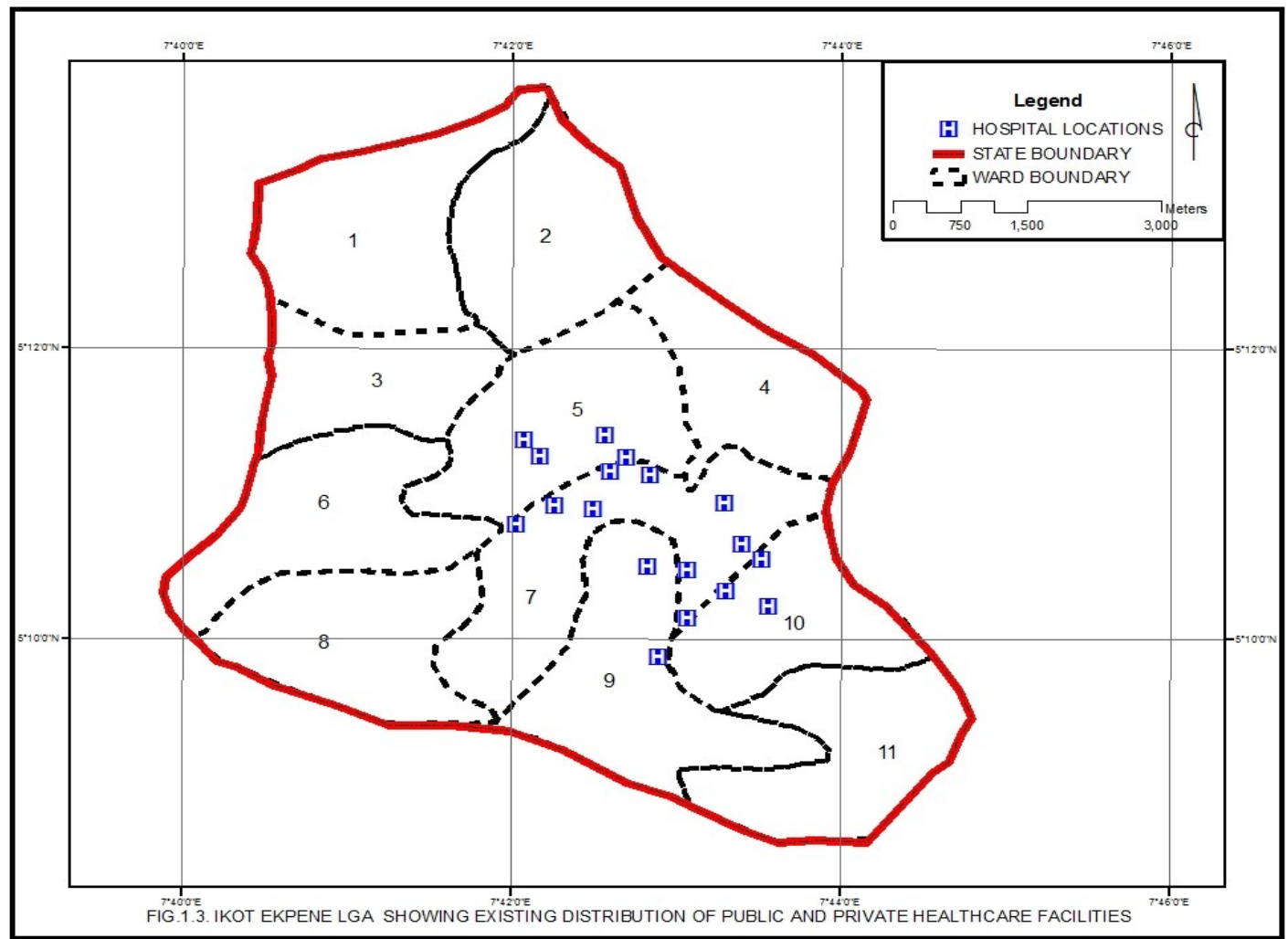

Fig. 4. Spatial Distribution of Health care Facilities in Ikot Ekpene LGA.

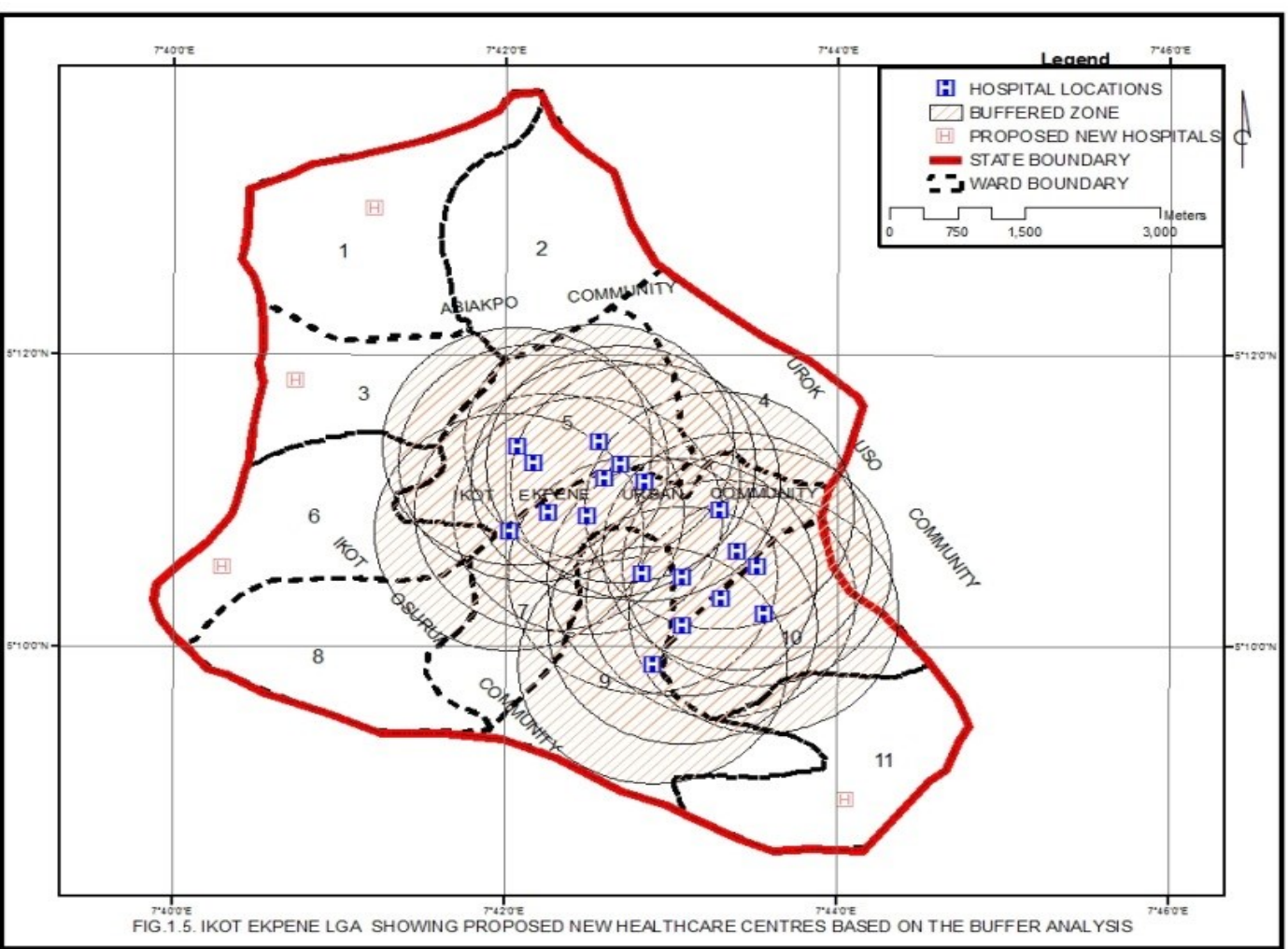

Fig. 5. $1 / 4 \mathrm{~km}$ buffer identifying areas served within $1 / 4 \mathrm{~km}$. 
On-screen digitization was done on features such as roads, rivers, and ward boundaries. Wards and health care facilities were digitized as polygons and points features respectively. These spatial data were organized in layers. The criteria used were according to WHO (1997) distance criteria of $1 / 4 \mathrm{~km}$ in locating health facilities from residential settlements.

\section{RESULTS AND DISCUSSION}

Data was collected on the total number of healthcare facilities and their characteristics in the study area with a view to analyzing their spatial distribution. The study area is made up of 11 wards with 1 general hospital, 1 specialized public health center and 18 private health centers. As shown in Fig. 2, private health centers account for $90 \%$ of the health facilities in the area. Available health facilities in the study area are concentrated within a few wards. Specifically, 3 wards namely, ward 5; ward 7 and ward 9 constituting about $27 \%$ of the number of wards actually have 18 of the healthcare facility about $80 \%$ of the healthcare facilities. This reveals obvious geographical imbalance in the location of such facilities.

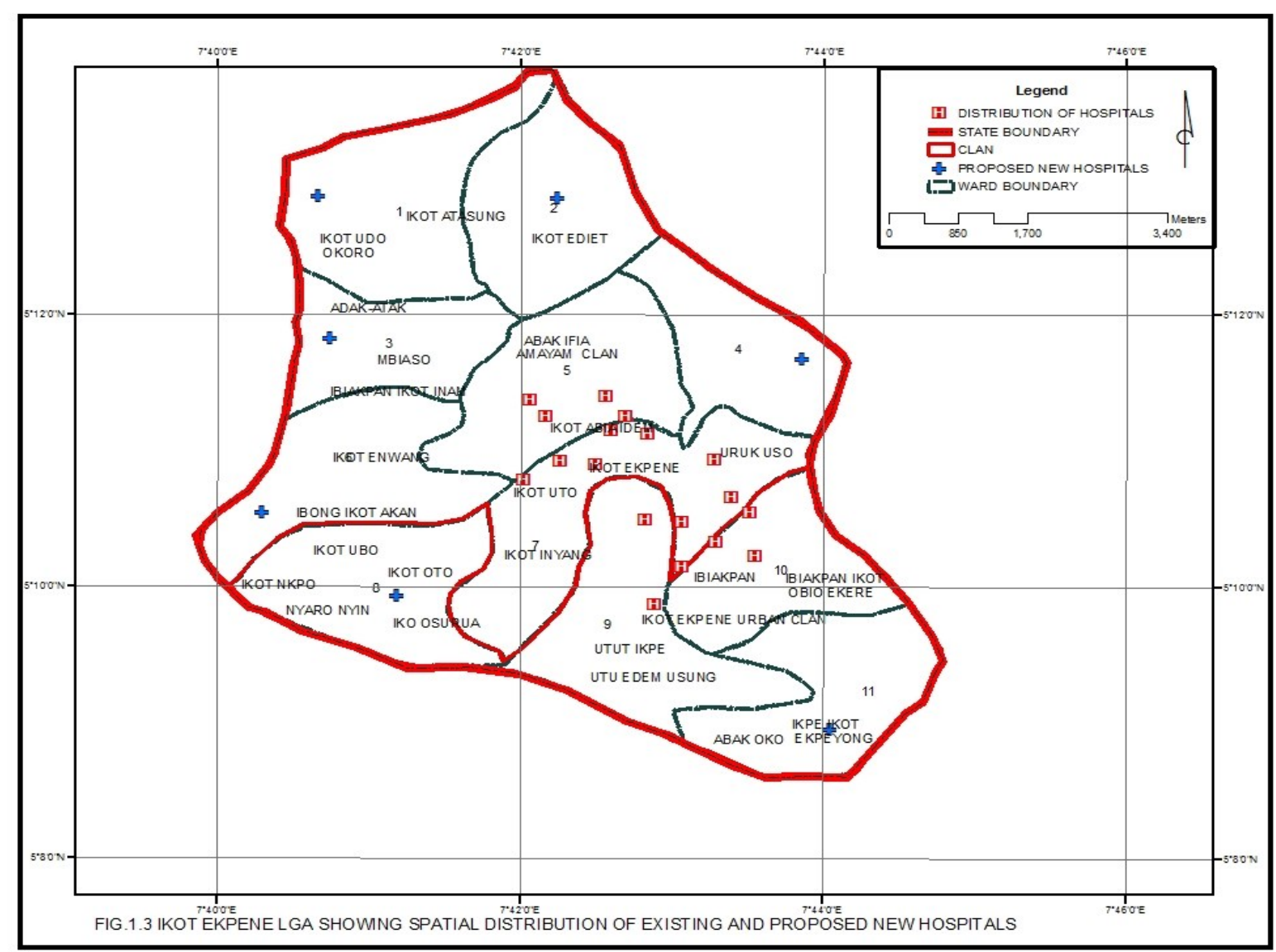

Fig. 6. Map of Ikot Ekpene showing Spatial Distribution of Health Care facilities including proposed sites for potential facilities. 
To determine areas effectively served by the available health facilities using WHO (1997) 1/4 distance criterion, a 250-meters buffer was generated (see Figure 5) All the areas within the buffer rings typifies effectively served locations with minimum travel distance for accessing health care facilities. It is obvious from Figure 5 that a large part of the LGA is under-served while there is a concentration of health facilities in the central wards. In reality, however, such observed pattern may be accounted for by population distribution pattern and/or related political or economic reasons. This is more so given the profit driven behavior of private health care providers. For effective and efficient coverage of the area within the WHO framework, 7 more healthcare facilities were proposed as in Figure 6. It therefore follows that if accessibility and utilization is given priority the seven proposed sites together with the existing facilities constitute the best possible location pattern for the healthcare facilities.

\section{CONCLUSION AND RECOMMENDATIONS}

The importance of efficient location of public facilities in different planning context such as healthcare has been recognized. Despite this recognition, a practical way of achieving this feat has always posed a challenge to healthcare facility managers, public decision makers and spatial planners in general. In the current study, the enviable capacity of GIS to solve locational problems in healthcare planning and similar contexts has been demonstrated. Location of health care facilities was found to be clustered within a few wards and hence is inefficiently distributed. Factors such a profit, population distribution and /or political and social reasons could be implicated in the observed location pattern. To achieve an efficient and cost-effective health care delivery, effort must be made to ensure that available health care facilities are located in such a way that maximum possible access and utilization could be achieved. Given scarcity of fund and current standard of living in the LGA and indeed Nigeria, all hands should be on deck to ensure unrestricted access to public facilities by the populace.

\section{References}

[1] Abbas Idowu Innocent, Auta Sarah Zaka, Na'iya Rakiya Muhammad, Global Journal of Human Social Science Geography \& Environmental GeoSciences 12(10) Version 1.0 (2012) 11-18.

[2] Gatakaa H., Noor A. M., Williams T.N., Bauni E., et al (2010). Geographic Access To Care is Not A Determinant Of Child Mortality In A Rural Kenyan Setting With High Health Facility Density. BMC Public Health 10: 142.

[3] Law M. R., Morris J. R., Journal of Epidemiology Community Health 52 (1998) 344-352,

[4] Njoku E. A (2001). Locational Efficiency of Maternity Centers in Ibadan North LGA. Unpublished BSc thesis, Department of Geography, University of Ibadan.

[5] Onokerhoraye A. G., Journal Socio-Economic Planning Science 10 (1979) 237-240.

[6] Pyle Gerald F. (1979). "Studies of Disease Diffusion." Applied Medical Geography. V. H. Winston \& Sons, Washington, D.C., 1979, pp. 139. 
[7] Rytkonen Mika J. P., International Journal of Circumpolar Health 63(1) (2004) 18.

[8] Schoeps A., Gabrysch S., Niamba L., Sie A., Becher H., Am. J. Epidemiology 173 (2011) 492-498.

[9] Sohel N, Do T. T., Eriksson L., Persson L. A., BMC Public Health 10 (2010) 762.

( Received 04 October 2013; accepted 17 October 2013 ) 